\title{
TO COMPARE THE EFFICACY OF LABETALOL AND METHYLDOPA IN TREATMENT OF PREGNANCY INDUCED HYPERTENSION
}

\section{Dr. Äshish Yadav \\ Dr. Rohitash Kularia}

Dr. Subash Chandra

\section{Dr. Anita Sharma*}

\author{
Resident Doctor, Department of General medicine, Sardar Patel Medical \\ College, Bikaner.
}

Associate professor, Department of General medicine, Sardar Patel Medical College, Bikaner.

Associate professor, Department of General medicine, Sardar Patel Medical College, Bikaner.

Associate professor, Department of Obstetrics and Gynecology, S. P. Medical College, Bikaner. ${ }^{*}$ Corresponding Author

ABSTRACT Background- The present study is undertaken with limited available facilities to find out the efficacy of two oral antihypertensive drugs namely labetalol and methyldopa in management of pregnancy

induced hypertension.

Methods- The study consisted of 100 patients with pregnancy induced hypertension attending outpatient department and admitted in ANW, or who directly came to labour room. These patients were randomly selected on lottery basis after they fulfilled the inclusion criteria. Total 100 patients were taken for the study and divided into 2 groups of 50 patients in each group. Results- The mean SBP before treatment in methyldopa group wasl61.33 $\pm 8.97 \mathrm{mmHg}$ and $160.03 \pm 8.23 \mathrm{mmHg}$ in labetalol group which showed a fall to $138.61 \pm 6.67 \mathrm{mmHg}$ (methyldopa group) and $138.08 \pm 5.37 \mathrm{mmHg}$ (labetalol groups) after treatment. Fall of SBP was significant in both the groups. But inter group difference was not significant $(p>0.05)$. The mean DBP before treatment was $106.85 \pm 4.33 \mathrm{mmHg}$ in methyldopa group and $105.63 \pm 5.23 \mathrm{mmHg}$ in labetalol group which decreased to $89.31 \pm 6.51 \mathrm{mmHg}$ and $89.68 \pm 5.26 \mathrm{mmHg}$ respectively after treatment. Fall of DBP was significant in both the groups. But inter group difference was not significant ( $p>0.05$ ). Fall of MAP was significant in Group A and Group B. But inter group difference was not significant $(\mathrm{p}>0.05)$.

Conclusion-Labetalol and methyldopa are equally efficacious in controlling blood pressure in new onset hypertension in pregnancy.

\section{KEYWORDS : Labetalol, Methyldopa, Hypertension.}

\section{INTRODUCTION}

The modern obstetrical approach has been stepped up to keep the mother as well as the fetus away from the deleterious effects of maternal disease like hypertension till the pregnancy reaches its goal safely. But multifactorial behaviour of hypertension with individual variations makes the matter more complicated.

Early diagnosis, close medical supervision and timely delivery are the cardinal requirements of the management of the PIH. Antihypertensive drugs are often used to lower blood pressure with the aim of preventing this progression to adverse outcomes. There is now very strong evidence to support the use of anti hypertensive agents in all form of hypertension. Severe hypertension, conventionally defined as a BP of $>160 / 110 \mathrm{mmHg}$, should be treated to prevent severe maternal complications. ${ }^{2-3}$

Alpha Methyldopa is an -methyl analogue of dopa, the precursor of dopamine (DA) and noradrenaline. Methyldopa is the most frequently prescribed and the agent of first choice for treatment of hypertension in pregnancy. There is extensive clinical experience and long-term follow-up data regarding children whose mothers received methyldopa during pregnancy with proven maternal and fetal safety. Methyldopa is a weak antihypertensive drug that needs to be given three or four times a day and frequently requires titration and nonadherence to therapy ${ }^{4}$

Labetalol blocks both $\alpha$ - and $\beta$-adrenoceptors and produces its hypotensive effects without compromising the maternal cardiovascular system, and maintains renal and uterine blood flow. Little placental transfer occurs, mainly due to the negligible lipid solubility of the drug. Not only does labetalol satisfactorily control BP in pregnant women but may possibly aid the maturation of the fetal lung in utero. ${ }^{5}$

The present study is undertaken with limited available facilities to find out the efficacy and safety of two oral antihypertensive drugs namely labetalol and methyldopa in management of pregnancy induced hypertension with the following aims and objectives.

\section{MATERIAL AND METHODS}

Study Design:

This study was hospital based comparative prospective study which included patients with pregnancy induced hypertension, attending the Antenatal Outpatient Department and admitted in Antenatal Ward or directly attending the labour room.

\section{Study Population:}

The study consisted of 100 patients with pregnancy induced hypertension attending outpatient department and admitted in ANW, or who directly came to labour room. These patients were randomly selected on lottery basis after they fulfilled the inclusion criteria. Total 100 patients were taken for the study and divided into 2 groups of 50 patients in each group.

The cases were selected and divided into two groups Group $A$ and Group B. Each case with odd number was selected in the Group A and each case with even no. was selected in the Group B. Group A patients were treated with methyldopa and Group B patients treated with labetalol.

\section{SELECTION OF CASES:}

Inclusion Criteria For Study Included The Following:

- A singleton pregnancy.

- Patients who were booked before 20 weeks of gestation were taken up after they cross 20 weeks of gestation.

- Blood pressure exceeding 150 and $100 \mathrm{~mm}$ of $\mathrm{Hg}$, systolic 
and diastolic respectively.

Exclusion Criteria Included Those With A:

- History of diabetes

- Rhesus iso-immunization

- Cardiac Diseases

- Asthma

- Patients previously given anti-hypertensive drugs

- Patients at risk of major obstetric complicationsantepartum haemorrhage, malnutrition, twins, hydramnious during current pregnancy.

- The cases those were not booked before $20^{\text {th }}$ weeks of pregnancy.

- The patients who came with any complications like eclampsia, IUFD, preterm labour, abruptio placentae, LVF, cerebrovascular accident, DIC and also the cases with symptoms of imminent eclampsia.

- Patients not willing to be hospitalized.

\section{Method Of Data Collection}

An elaborate history was taken. General physical examination and systemic examinations were done.

Blood pressure record was maintained after delivery till discharge. On discharge, discharge card was given and postoperative visits after 6 weeks, 12 weeks were advised.

\section{RESULTS}

Table-1. Age Distribution Of Patients In Group Ā Ānd Group B \begin{tabular}{|l|l|l|}
\hline AGE GROUP(in years) & GROUPA (n=75) & GROUP B ( $(n=75)$ \\
\hline
\end{tabular}

\begin{tabular}{l|l}
\hline $25.2 \pm 4.68$ & $23.65 \pm 4.61$ \\
\hline
\end{tabular}

The mean age in groups A was $25.2 \pm 4.68$ years and in Group B $23.65 \pm 4.61$ years. The inter group difference was not statistically significant $(p>0.05)$ thus the two groups were comparable by age.

Table-2. Mean Blood Pressure Level Of Study Groups Before Treatment

\begin{tabular}{|c|c|c|c|c|c|c|}
\hline \multicolumn{2}{|c|}{\begin{tabular}{|l|} 
BLOOD \\
PRESSURE \\
\end{tabular}} & \multicolumn{2}{|l|}{ GROUPA } & \multicolumn{2}{|l|}{ GROUPB } & \multirow{2}{*}{\begin{tabular}{|l}
$\begin{array}{l}\text { p- } \\
\text { value }\end{array}$ \\
\end{tabular}} \\
\hline & & Range & $\begin{array}{l}\text { Mean BP } \\
\pm \text { SD } \\
(\mathrm{mmHg})\end{array}$ & Range & $\begin{array}{l}\text { Mean } \\
\mathrm{BP} \pm \mathrm{SD} \\
(\mathrm{mmHg})\end{array}$ & \\
\hline \multirow[t]{3}{*}{ SBP } & Before & $150-184$ & \begin{tabular}{|l}
$161.33 \pm$ \\
8.97
\end{tabular} & $\begin{array}{l}=150- \\
182\end{array}$ & $\begin{array}{l}160.03 \pm \\
8.23\end{array}$ & $>0.05$ \\
\hline & After & $130-152$ & \begin{tabular}{|l|}
$138.61 \pm$ \\
6.67 \\
\end{tabular} & $\begin{array}{l}130- \\
152\end{array}$ & $\begin{array}{l}138.08 \pm \\
5.37\end{array}$ & $>0.05$ \\
\hline & $\mathrm{p}$-value & $<0.05$ & & $<0.05$ & & \\
\hline \multirow[t]{3}{*}{ DBP } & Before & $100-120$ & \begin{tabular}{|l|l}
$106.85 \pm$ \\
4.33 \\
\end{tabular} & $=100-120$ & \begin{tabular}{|l|}
$105.63 \pm$ \\
5.23 \\
\end{tabular} & $>0.05$ \\
\hline & After & $80-104$ & \begin{tabular}{|l|}
$89.31 \pm$ \\
6.51 \\
\end{tabular} & $80-104$ & $\begin{array}{l}89.68 \pm \\
5.26 \\
\end{array}$ & $>0.05$ \\
\hline & $\mathrm{p}$-value & $<0.05$ & & $<0.05$ & & \\
\hline \multirow[t]{3}{*}{ MAP } & Before & $\begin{array}{l}116.66- \\
140.66\end{array}$ & \begin{tabular}{|l}
$125.01 \pm$ \\
4.39
\end{tabular} & $\begin{array}{l}116.66- \\
140\end{array}$ & $\begin{array}{l}123.76 \pm \\
4.45\end{array}$ & $>0.05$ \\
\hline & After & $\begin{array}{l}116.66- \\
140.66\end{array}$ & $\begin{array}{l}105.74 \pm \\
5.16\end{array}$ & $=96.66-120$ & $\begin{array}{l}105.81 \pm \\
4.04\end{array}$ & $>0.05$ \\
\hline & $\mathrm{p}$-value & $<0.05$ & & $<0.05$ & & \\
\hline
\end{tabular}

The mean SBP before treatment in methyldopa group was $161.33 \pm 8.97 \mathrm{mmHg}$ and $160.03 \pm 8.23 \mathrm{mmHg}$ in labetalol group which showed a fall to $138.61 \pm 6.67 \mathrm{mmHg}$ (methyldopa group) and $138.08 \pm 5.37 \mathrm{mmHg}$ (labetalol groups) after treatment. Fall of SBP was significant in both the groups. But inter group difference was not significant $(p>$ 0.05). The mean DBP before treatment was $106.85 \pm 4.33$ $\mathrm{mmHg}$ in methyldopa group and $105.63 \pm 5.23 \mathrm{mmHg}$ in labetalol group which decreased to $89.31 \pm 6.51 \mathrm{mmHg}$ and $89.68 \pm 5.26 \mathrm{mmHg}$ respectively after treatment. Fall of DBP was significant in both the groups. But inter group difference was not significant ( $p>0.05$ ). Fall of MAP was significant in Group A and Group B. But inter group difference was not significant $(p>0.05)$. On comparing methyldopa and labetalol groups mean blood pressure before and after treatment was not statistically significant $(p>0.05)$. Reduction in SBP, DBP, MAP was significant $(p<0.05)$ in both the groups after treatment but intergroup difference in fall in blood pressure was not statistically significant $(p>0.05)$.

\section{DISCUSSION}

100 patients with pregnancy induced hypertension, who attended the antenatal outpatient department and admitted or directly came to the labour room had been studied. The patients were divided into 2 groups: Group A patients were treated with methyldopa and Group B patients were treated with labetalol.

In the present study fall of SBP, DBP and MAP was significant in both the groups. But the inter group difference was statistically not significant $(p>0.05)$. The mean SBP before treatment in methyldopa group wasl61.33 $\pm 8.97 \mathrm{mmHg}$ and $160.03 \pm 8.23 \mathrm{mmHg}$ in labetalol group which showed a fall to $138.61 \pm 6.67 \mathrm{mmHg}$ (methyldopa group) and $138.08 \pm 5.37$ $\mathrm{mmHg}$ (labetalol groups) after treatment. Fall of SBP was significant in both the groups. But inter group difference was not significant $(p>0.05)$. The mean DBP before treatment was $106.85 \pm 4.33 \mathrm{mmHg}$ in methyldopa group and $105.63 \pm 5.23$ $\mathrm{mmHg}$ in labetalol group which decreased to $89.31 \pm 6.51$ $\mathrm{mmHg}$ and $89.68 \pm 5.26 \mathrm{mmHg}$ respectively after treatment. Fall of DBP was significant in both the groups. But inter group difference was not significant ( $p>0.05$ ). Fall of MAP was significant in Group A and Group B. But inter group difference was not significant $(p>0.05)$. Similar results were shown by study conducted by Qasim et al, in which patients treated with Labetalol systolic/diastolic BP on admission (lst day) was $150 \pm 9 \mathrm{mmHg} / 100 \pm 8 \mathrm{mmHg}$ respectively and was controlled to $123 \pm 9 \mathrm{mmHg} / 79 \pm 7 \mathrm{mmHg}$ on day 7 th while systolic/diastolic BP in Methyldopa treated group on the day of admission (lst day) was $148 \pm 8 \mathrm{mmHg} / 102 \pm 9 \mathrm{mmHg}$ which was reduced to $125 \pm 10 \mathrm{mmHg} / 82 \pm 6 \mathrm{mmHg} .18$ Statistically significant reduction in systolic/diastolic BP was observed in case of Labetalol treated group. ${ }^{6}$ This is in accordance with the study done by Lamming et al. ${ }^{7}$ Study conducted by El Qarmalawi et $\mathrm{al}^{8}$ says that Labetalol provides more efficient control of BP than Methyldopa in treatment of hypertension in pregnancy. In a study conducted by Wallin JD and Wilson D, Eighty-one severely hypertensive patients were enrolled in a multicenter, double-blind, parallel group study evaluating the efficacy and safety of Labetalol alone or in combination with furosemide versus Methyldopa in combination with furosemide. ${ }^{9}$

\section{CONCLUSION}

Labetalol and methyldopa are equally efficacious in controlling blood pressure in new onset hypertension in pregnancy.

\section{REFERENCES}

1. Abalos E, Duley L, Steyn DW, Henderson-Smart DJ. Antihypertensive drug therapy for mild to moderate hypertension during pregnancy. Cochrane Database of Systematic Reviews 2007, Issue 1. Art. No.: CD002252. DOI: 10.1002/14651858.CD002252.pub2.

2. Al-Damluji SF, Al-Khalidi A, Shaarbaf H. Tawfig NH. A controlled comparison of the antihypertensive effects of labetalol and alpha-methyldopa. Pharmatherpeutica 1982;3(2):133-9.

3. Duley L, Henderson-Smart DJ, Meher S. Drugs for treatment of very high blood pressure during pregnancy. Cochrane Database Syst Rev. 2006:CD001449.

4. Steegers EA, von Dadelszen P, Duvekot JJ, Pijnenborg R. Preeclampsia. Lancet. 2010;376:631-44.

5. Duckitt K, Harrington D. Risk factors for preeclampsia at antenatal booking: systematic review of controlled studies. BMJ. 2005;330:565.

6. Qasim A, Siddiqui MH, Salam JU, Nusrat U. Labetalol versus Methyldopa: efficacy in pregnancy induced hypertension. Gomal J Med Sci. 2014;12:233-6.

7. ACOG Committee on Obstetric Practice. ACOG practice bulletin. Diagnosis and management of preeclampsia and eclampsia. Number 33, January 2002. Am College Obstet Gynecol. Int J Gynaecol Obstet. 2002;77:67-75.

8. El-Qarmalawi AM, Morsy AH, Al-Fadly A, Obeid A, Hashem M. Labetalol vs Methyldopa in the treatment of pregnancy-induced hypertension. Int J Gynecol Obstet. 1995:49:125-30.

9. Wallin JD, Wilson D, Winer N, Maronde RF, Michelson EL, Langford H, et al Treatment of severe hypertension with Labetalol compared with Methyldopa and furosemide. Am J Med. 1983;75(4A):87-94. 